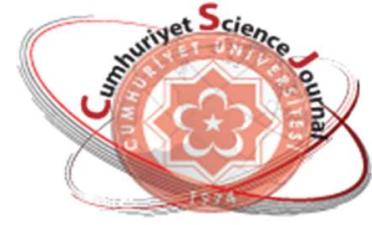

Cumburiyet Science Journal

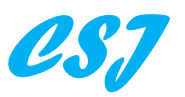

e-ISSN: $2587-246 X$

ISSN: $2587-2680$

\title{
Comparison of Remote Sensing Classification Techniques for Water Body Detection: A Case Study in Atikhisar Dam Lake (Çanakkale)
}

\author{
Emre ÖZELKAN (iD) \\ Çanakkale Onsekiz Mart University, Faculty of Architecture \& Design, Department of Urban \& Regional \\ Planning, Çanakkale, TURKEY.
}

\begin{abstract}
Water resources management is one of the most important issues of today. Satellite remote sensing have been successfully used to detect the presence of water bodies. In this study, four remote sensing methods: (1) normalized difference water index (NDWI), (2) support vector machine (SVM), (3) geographic object-based image analysis (GEOBIA) and (4) NDWI supported GEOBIA (GEOBIA_NDWI) were examined for water body area detection. For this purpose, Atikhisar Dam Lake, the only water source of Çanakkale central district of Turkey was selected as study area. As remote sensing data nine multitemporal Landsat-8 Operational Land Imager (OLI) multispectral satellite images between 2013 and 2017 were used. For the accuracy assessment, area values extracted from the used methods were tested with in-situ measurement lake area values. The main issues discussed in this study can be specified as follows: (i) Is pixel-based classification SVM or object-based image classification GEOBIA more successful in the water body detection?, (ii) Are the image classification methods (SVM and GEOBIA) or the water index (NDWI) more successful in the water body detection? and (iii) What is the contribution of NDWI to GEOBIA_NDWI (GEOBIA_NDWI) classification in the water body detection? The results show that meteorological factors and irrigation were influential in lake area variations. NDWI was found to be superior to other methods in determining water body and allowed for better detection of the lake boundary. Additionally, NDWI made a better separation of the land cover classes adjacent to water at the border. The object based GEOBIA was better than the pixel based SVM for distinguishing water and other land cover classes adjacent to border. GEOBIA_NDWI lake area results were more accurate than the standard object-based classification. Mixed pixels out of the lake area was determined less in the NDWI and GEOBIA_NDWI results.
\end{abstract}

Keywords: Water body detection, NDWI, SVM, GEOBIA, GEOBIA_NDWI.

\section{Su Kütlesi Belirlemede Farklı Sınıflandırma Yöntemlerinin Karşılaştırılması: Atikhisar Barajı (Çanakkale) Örneği}

Özet. Su kaynakları yönetimi günümüzün en önemli konularının başında gelmektedir. Su kütlelerinin varlığının tespitinde uydudan uzaktan algılama başarı ile kullanılmaktadır. Bu çalışmada, (1) normalize edilmiş fark su indisi (NDWI), (2) destek vektör makinaları (DVM), (3) coğrafi nesne-tabanlı görüntü analizi (GEOBIA) ve NDWI destekli GEOBIA (GEOBIA_NDWI) uzaktan algılama yöntemleri su kütlesini belirleyebilmek için incelenmiştir. Bu amaçla, Türkiye'nin Çanakkale İl'inin Merkez İlçe'sinin tek su kaynağı olan Atikhisar Baraj Gölü çalışma alanı olarak tercih edilmiştir. Uzaktan algılama verisi olarak, 2013 ve 2017 yılları arasında temin edilmiş, dokuz adet çok zamanlı Landsat-8 Operational Land Imager (OLI) multispektral uydu görüntüsü kullanılmıştır. Kullanılan yöntemlerden elde edilen sonuçların doğruluk analizi için, yerinde ölçülen göl alanı değerleri kullanılmıştır. Bu çalışmada ele alınan ana konular şu şekilde sıralanabilir: (i) Piksel tabanlı sınıflandırma DVM mi yoksa nesne tabanlı sınıflandırma GEOBIA mı su kütlesi belirlemede daha başarılıdır?, (ii) Görüntü sınıflandırma yöntemleri mi (DVM ve GEOBIA) yoksa su indisi mi (NDWI) su kütlesi belirlemede daha başarılıdır? ve (iii) NDWI'ın GEOBIA_NDWI sınıflandırmasına su kütlesi belirlemede katkısı nedir? 
Sonuçlar meteorolojik etkenlerin ve sulamanın göldeki değişimlerde etkili olduğunu göstermektedir. NDWI göl alanı belirlemede daha başarılı bulunmuştur ve göl sınırı belirlemede daha iyi sonuç vermektedir. Ek olarak, NDWI göl kenarında su ile temas eden sınıfları daha iyi ayırabilmektedir. Nesne tabanlı GEOBIA suyla temas eden arazi örtüsü sınıflarını piksel tabanlı DVM'den daha iyi ayırabilmektedir. GEOBIA_NDWI sonuçları standart nesne tabanlı sinıflandırmadan daha doğrudur. NDWI ve GEOBIA_NDWI sonuçlarında göl alanı dışında su olarak atanmış piksel sayısı daha azdır.

Anahtar Kelimeler: Su kütlesi belirleme, NDWI, DVM, GEOBIA, GEOBIA_NDWI.

\section{INTRODUCTION}

Water is the most vital resource for the continuity of all life on earth. Water resources management is the most important issue of today due to the decreasing water resources and increasing water demand [1]. Moreover, global warming and climate change that continually increase their destructive effect makes the precision water resources management important more than ever in the management of the agricultural irrigation $[2,3]$. Since the lack of water adversely affects whole life, water resources need to be managed in the most accurate and effective manner $[4,5]$.

The most basic and known way to detect the location, size and content of the water bodies is to make in situ measurements and observations. However, these measurements and observations are not effective as time and cost. Continuity of observations and measurements is extremely important especially in arid and semi-arid climates, where monthly and seasonal changes are significant. Remote sensing is widely used efficiently in the management of water resources $[6,7]$. Remote sensing from the satellite provides a great advantage in monitoring water bodies owing to the ability to extract information about large areas at once [7]. In other words, satellite remote sensing makes continuous monitoring of water resources possible in a time- and cost-effective way $[4,6]$.
There are several remote sensing methods for detecting water bodies, and image classification and water indices are some of the most preferred methods [8-11]. The methods of image classification are generally divided into supervised and unsupervised, and, however, supervised classification is most preferred in terms of accuracy and reliability [12]. Some of the popular supervised classification methods are Maximum Likelihood, Spectral Angle Mapper, Neural Network and Support Vector Machine (SVM) [12, 13]. On the other hand, image classification methods are divided into pixel and object-based [14]. While the pixel-based classification classifies the pixels according to the spectral characteristics of the image, the basic approach in the object-based classification is to create homogeneous image objects from image pixels with similar spectral properties and to classify these objects by taking into account the spectral, statistical, texture and geometric characteristics defined for these objects $[15,16]$. The most commonly used object-based classification method is eCognition's geographic object-based image analysis (GEOBIA) software system [17].

Water indices are the most effective and easy way to detect water bodies with remote sensing. Water indices are composed of simple algorithms performed by spectral bands considering the 
spectral properties of water that are high reflectance in visible and low reflectance in infrared regions such as normalized difference water index (NDWI) [18] and modified NDWI [19]. In spite of their simple structures and working principles, water indices can produce faster and more accurate information than other methods [9]. There are many successful studies conducted with SVM [20], GEOBIA [21] and NDWI [22] methods for determining the water body. On the other hand, the water body extraction studies, where GEOBIA is supported by indices such as NDWI comprising the most basic and useful band arithmetic, are also increasing [23-25].

In this study, the water body area detection capability of four methods: (1) normalized difference water index (NDWI), (2) support vector machine (SVM) - a supervised classification method, (3) geographic object-based image analysis (GEOBIA) and (4) NDWI supported GEOBIA (GEOBIA_NDWI) were investigated. As a study area Atikhisar Dam Lake in Çanakkale province of Turkey was selected and as remote sensing data nine multitemporal Landsat- 8 Operational Land Imager (OLI) multispectral satellite images between 2013 and 2017 were used. Contrary to the classical approach in accuracy assessment such as using high spatial resolution images, maps, ground control points with GPS, etc., the extracted lake area values using remote sensing methods were verified by in-situ measured lake area values. Considering the above assessments and approaches, the main issues discussed in this study can be specified as follows: (i) Is pixel-based classification (SVM) or objectbased image classification (GEOBIA) more successful in the water body detection?, (ii) Are the image classification methods (SVM and GEOBIA) or the water index (NDWI) more successful in the water body detection? and (iii) What is the contribution of NDWI to GEOBIA (GEOBIA_NDWI) classification in the water body detection?

\section{MATERIALS AND METHODS}

\subsection{Study Area}

The study area is Atikhisar Dam Lake located between 26³1'2.22" - 26³3'10.30" eastern meridians and $40^{\circ} 7^{\prime} 36.31^{\prime \prime}-40^{\circ} 3^{\prime} 49.67^{\prime \prime}$ northern parallels within the borders of Canakkale city established in the west of the Turkey (Figure 1). Atikhisar Dam is crucial for the region since it is the only water source of the central district and serves as a multi-purpose dam providing drinking water, irrigation, flood protection, etc [4]. The study area is located in the Marmara climate, which is a regional transition zone between the Black Sea and Mediterranean climates [26]. According to Turkish State Meteorological Service long term data: (a) The rainiest and driest months are December with $106.8 \mathrm{~mm}$ and August with 6.4 $\mathrm{mm}$, respectively and (b) The hottest and the coldest months are July with $25 \mathrm{oC}$ and January with $6.1 \mathrm{oC}$, respectively.

\subsection{Field Data}

In the study area, all water level measurements are performed by the General Directorate of State Hydraulic Works (DSI) on the first day of the month. Field data from DSI observation and measurement station were acquired between 2013 and 2017. The remote sensing water body detection methods' results were verified by in-situ water area measurement values. As explained in the next 
section, only nine in-situ measurement data could be used because of the atmospheric constraints (fog, haze and cloud) in obtaining satellite images (Table 1). Additionally, the meteorological data (only precipitation for this study) from Turkish State Meteorological Service (MGM) was used to interpret results.
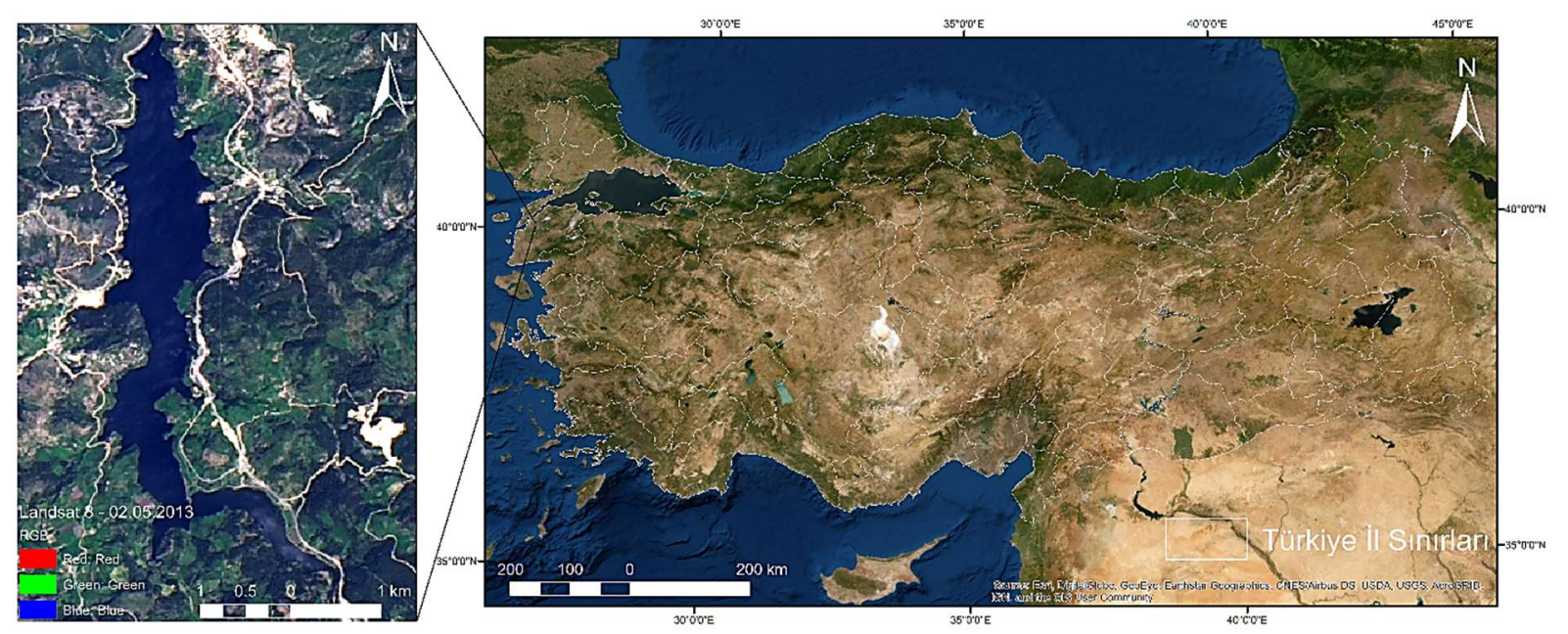

Figure 1: Study area.

Table 1: List of used images and difference from in-situ measurement day of image acquisition date.

\begin{tabular}{lccc}
\hline No & Image Acquisition Date & Path/Row & Difference from In-situ Measurement Day \\
\hline 1 & 02.05 .2013 & $181 / 32$ & 1 \\
2 & 30.09 .2013 & $182 / 32$ & 1 \\
3 & 02.07 .2015 & $182 / 32$ & 1 \\
4 & 02.06 .2016 & $182 / 32$ & 1 \\
5 & 01.10 .2016 & $181 / 32$ & 0 \\
6 & 02.11 .2016 & $181 / 32$ & 1 \\
7 & 02.04 .2017 & $182 / 32$ & 1 \\
8 & 30.06 .2017 & $181 / 32$ & 1 \\
9 & 02.09 .2017 & $181 / 32$ & 1 \\
\hline
\end{tabular}

\subsection{Remote Sensing Data and Processing}

The dates and numbers of the images used were determined by considering the dates of in-situ water level measurements performed on the first day of the month. Satellite images are procured on the same day as the local data or with a maximum difference of one day. On the other hand, during the selection of the images, attention was given to ensure that the study area is not covered by fog, haze and cloud. A total of nine Landsat 8
Operational Land Imager (OLI) multitemporal satellite images over the study area between 2013 and 2017 were utilized in this study (Table 1). In the process of preprocessing the remote sensing data, $15 \mathrm{~m}$ spatial resolution surface reflectance images were produced by using ENVI software's Quick Atmospheric Correction (QUAC) and nearest-neighbor diffusion-based (NNDiffuse) pan-sharpening algorithms. 
In this study, the water body area detection capability of four methods: (1) NDWI, (2) SVM a supervised classification, (3) GEOBIA and (4) GEOBIA_NDWI were investigated and these classification methods can be explained as follows:

(1) NDWI is one of the most commonly-used indices to detect water bodies, and was composed of the green (high reflectance of water) and nearinfrared (NIR) (low reflectance of water) spectral bands of Landsat initially [18] and then used for different remote sensing data [22]. The results of the NDWI formula (Green - NIR)/(Green + NIR) range from -1 and 1 . In the study of McFeeters, NDWI's values greater than 0 are considered as water and values below 0 mean other land use/cover classes [18].

(2) SVM is a supervised classification algorithm based on statistical learning theory [12]. The working principle of SVM is based on the principle of defining the most appropriate decision function which can distinguish classes, in other words, defining the hyper-plane that separates the classes in the most accurate way $[12,16]$. In the SVM classification, the default set of parameters (Kernel Type: Radial Basis Function, Gamma in the Kernel Function: 0.143, Penalty Parameter: 100, Pyramid Levels: 0 , and Classification Probability Threshold: 0 ) were employed by training region of interest values of land cover classes (water, vegetation and others).

(3) The basic approach in GEOBIA is to create homogeneous image objects (i.e. segmentation) from image pixels with similar spectral properties/signatures and then to classify these objects by considering the spectral, statistical, texture and geometric characteristics defined for these objects $[15,17]$. In this context, the GEOBIA method of eCognition software was applied for object-based image classification. For the purpose of consistency, the same set of parameters (image layer weights: 1 for visible bands and 2 for infrared bands for better discrimination between water and other classes, scale parameter: 10 , shape: 0.1 and compactness: 0.5 ) were utilized in segmentation process. The next stage after the segmentation is the classification of the segments, and in this study two options (methods 3 and 4) were preferred at this stage. The first is standard GEOBIA the implementation of the maximum likelihood classification algorithm to objects training by the samples from each land cover classes (water, vegetation and others), which is basically similar to the supervised classification $[14,27]$.

(4) The second approach in GEOBIA is to classify the objects according to the threshold values of another data set that may be bands of the satellite image from which the objects/segments are generated, or index images generated from this image $[25,28]$. In the GEOBIA_NDWI classification, water class assignment was done according to the acceptance that the objects' NDWI values greater than 0 are considered as water.

\subsection{Data Analysis}

The capability of the four methods (NDWI, SVM, GEOBIA, and GEOBIA_NDWI) was examined employing root mean square error (RMSE) and Pearson's correlation coefficients $(\mathrm{R})$ to correlate the computed data from remote sensing methods with validation data (i.e. field data). 


\section{RESULTS AND DISCUSSION}

NDWI, SVM, GEOBIA, and GEOBIA_NDWI methods' water body detection performances were investigated to examine the superiority between the pixel-based and the object-based classification, the superiority between the NDWI and the image classification methods and the contribution of the NDWI to the object-based classification.

The in-situ values showed that the lake generally reaches its largest and narrowest limits at the end of the rainy (between September and May) and the dry (between June and August) periods, respectively. According to the used data set, the average lake area value is $2.917 \mathrm{~km}^{2}$ and standard deviation is $0.546 \mathrm{~km}^{2}$ (Table 2). The lake area was narrowest on November 02, 2016 with $2.156 \mathrm{~km}^{2}$ (Figure 2). Under normal conditions, November is in the rainy season, however the main reason why the lake is narrowest on November 02, 2016 was the precipitation in September and October declined by $92 \%$ compared to the long-term average data that was a severe meteorological drought. On the other hand, the second reason of lack of water in lake area was agricultural irrigation in September. On the other side, although it was not the end of the rainy season, the lake reached its largest area on May 2, 2013 with $3.692 \mathrm{~km}^{2}$ (Figure 2). The extreme precipitation in January, February and April being almost twice the long-term average is the main reason of this early formation before the end of the rainy season. In addition, although July 2, 2017 was in the dry period, $3.434 \mathrm{~km}^{2}$ of lake area was formed, and the biggest reason for this is excessive precipitation $(65 \mathrm{~mm})$ that is more than twice the long-term average precipitation occurred in June 2017.

Table 2: Average, standard deviation, RMSE and average of deleted mixed pixels out of the lake area values of NDWI, SVM,

\begin{tabular}{cccccc}
\multicolumn{6}{c}{ GEOBIA and GEOBIA_NDWI (NDWI supported GEOBIA). } \\
\hline & NDWI & SVM & GEOBIA & GEOBIA_NDWI & In-situ Measurement \\
\hline Average lake areas $\left(\mathrm{km}^{2}\right)$ & 2.908 & 3.068 & 3.050 & 2.939 & 2.917 \\
Standard Deviation $\left(\mathrm{km}^{2}\right)$ & 0.490 & 0.631 & 0.654 & 0.507 & 0.546 \\
RMSE $\left(\mathrm{km}^{2}\right)$ & 0.067 & 0.177 & 0.179 & 0.083 & - \\
$\begin{array}{c}\text { Average of deleted mixed pixels } \\
\text { out of the lake area }\left(\mathrm{km}^{2}\right)\end{array}$ & 0.010 & 0.037 & 0.032 & 0.010 & - \\
\hline
\end{tabular}

All water body extraction methods produced minimum and maximum values on the same dates as in-situ lake measurements. When the average of the lake area values produced by the methods is examined, it is determined that the average of the lake area values produced by NDWI is the closest to the in-situ measurement values (Table 2). The second one is GEOBIA_NDWI and the worst is SVM. According to standard deviation value of the results the closest method to the in-situ values is GEOBIA_NDWI, the second is NDWI and the worst GEOBIA. In addition, the best results for the RMSE values are NDWI, followed by GEOBIA_NDWI, SVM and GEOBIA from low RMSE to high. On the other hand, pixels or objects remaining outside the lake area and mixed with other land use/cover classes were determined and deleted manually. Table 2 shows the mean of the 
deleted mixed pixel areas (i.e. assignment of water to non-water classes) resulting from the application of each method. The results show that NDWI and GEOBIA_NDWI methods produced the least mixed pixels. While the maximum mixing with other classes was occurred by SVM, there is only $0.25 \mathrm{~km}^{2}$ difference between the best and worst method. Each data set from investigated four methods have a high positive correlation over 0.990 with the data set composed of in-situ measured area values, and only 0.007 difference is available between the lowest (GEOBIA_NDWI) and highest (NDWI and SVM) correlation values (Figure 3). As a result of the evaluations, a scoring was performed using RMSE, deleted mixed areas and correlations. The methods generated smaller RMSE and mixed area were evaluated as more successful. On the other hand, for positive correlation, the greater the correlation value means that the $R$ value is close to 1 , i.e. the lower the value of 1 minus $\mathrm{R}(1-\mathrm{R})$, the higher the correlation.
When the simple evaluation equation $=($ RMSE + Deleted Mixed Pixels + (1 - R)) was applied, success ranking of the methods is as follows: NDWI $>$ GEOBIA_NDWI $>$ GEOBIA $>$ SVM.

Additionally, it was determined that the borders of the lake area could be determined more successfully with NDWI that use the advantage of high reflectance in visible and low reflectance in near infrared of water. Due to the positive effect of NDWI, GEOBIA_NDWI was found to be second. However, mixing with classes in contact with water at the boundary line was found to be less with GEOBIA compared to SVM. Although all the methods tested in this study produced reasonable results, the results produced with NDWI were superior to others. When all findings were evaluated together, it was concluded that all the methods tested in this study produce reasonable results, but the results produced with NDWI are superior to others. 


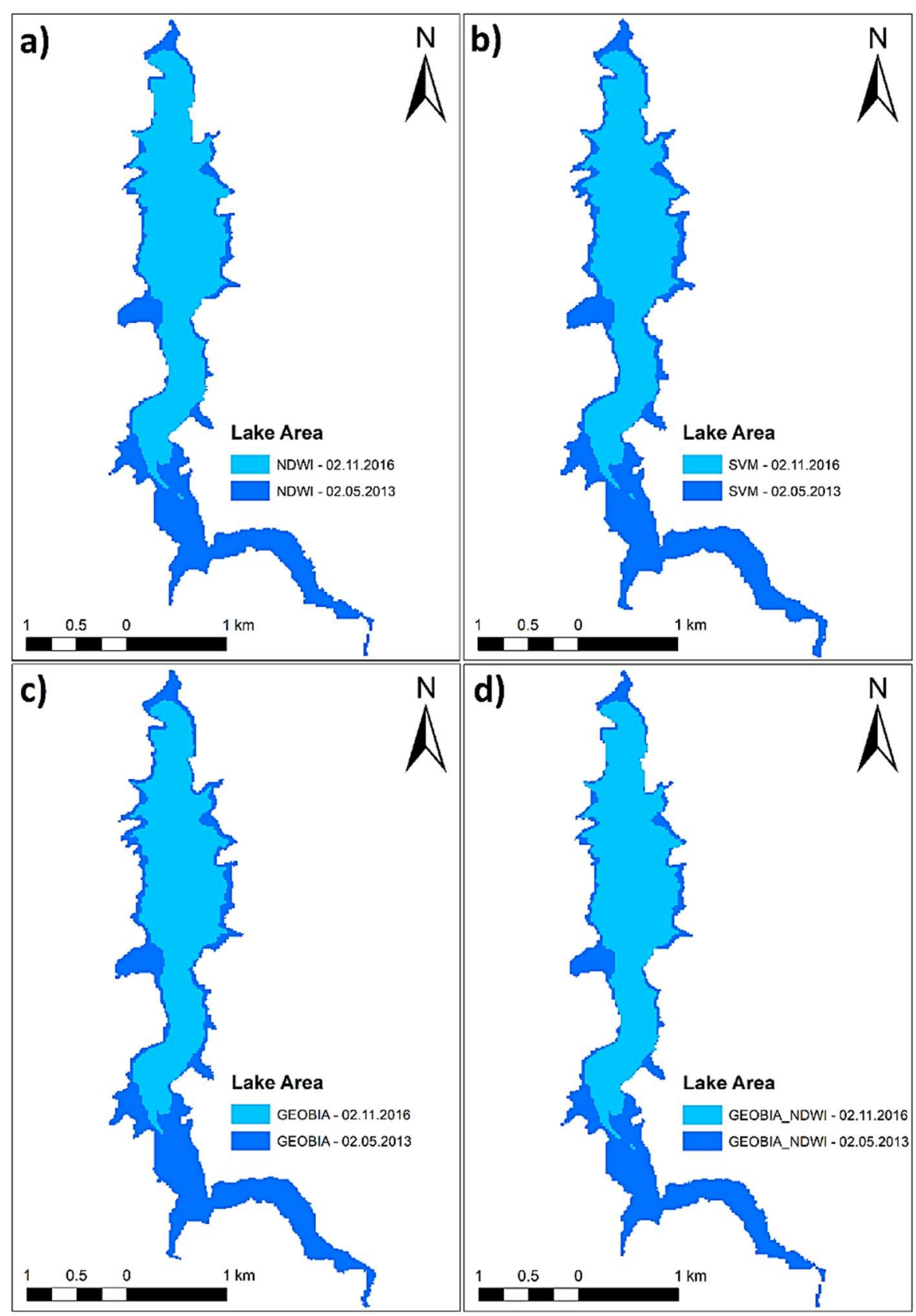

Figure 2: Lake area results from 02.05.2013 (maximum) and 02.11.2016 (minimum): a) NDWI, b) SVM, c) GEOBIA and d) GEOBIA_NDWI (NDWI supported GEOBIA). 

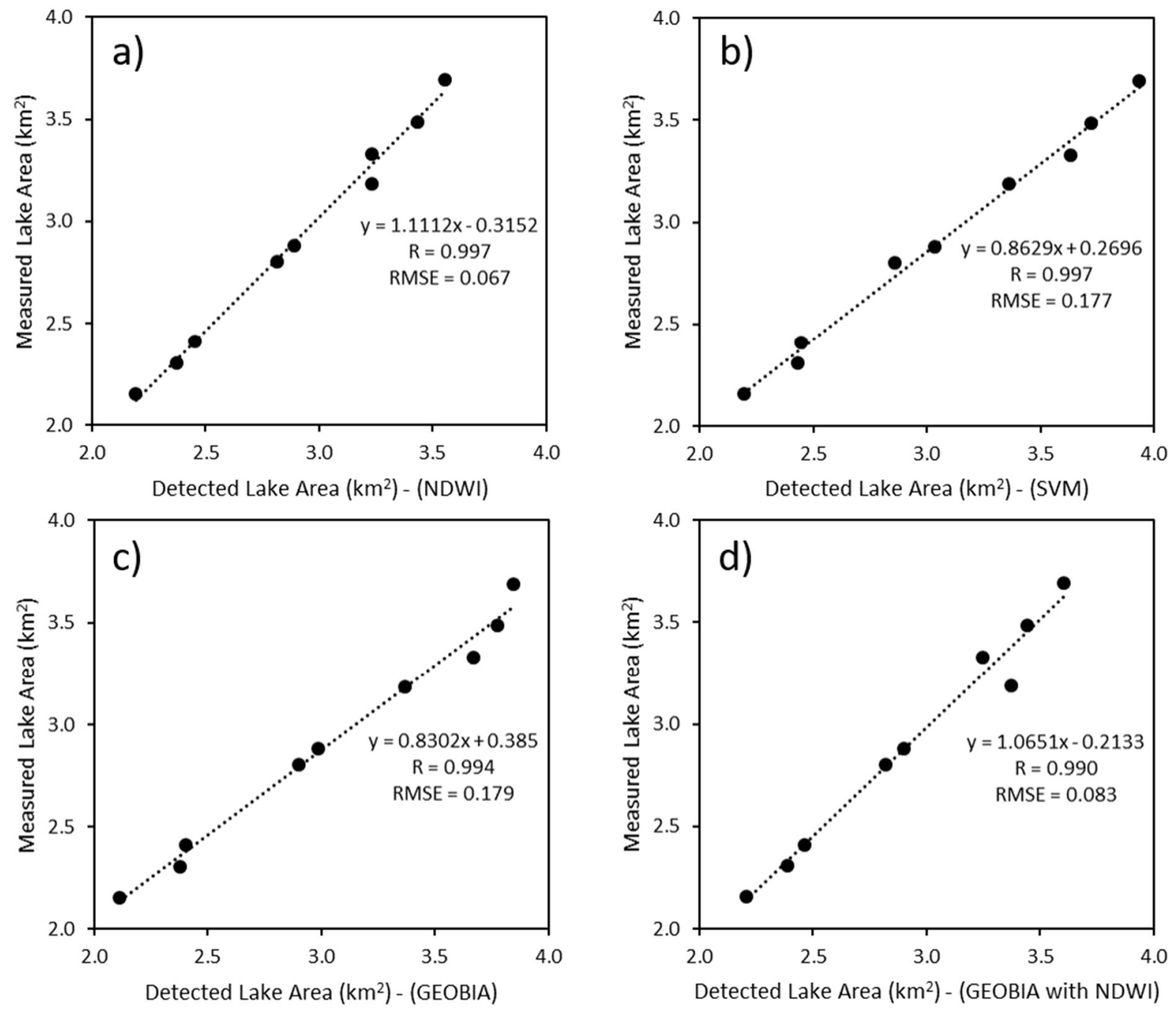

Figure 3: Correlations between in-situ and investigated methods' values: a) NDWI, b) SVM, c) GEOBIA and d) GEOBIA_NDWI (NDWI supported GEOBIA).

\section{CONCLUSION}

Increasing of human population, decreasing of sources, global warming and climate change are all the vital problems that cause most vital problem lack of water. Water resource management must be the most prominent issue today and future especially for arid and semi-arid climate regions. In this context, satellite technologies and remote sensing methods, which allow time- and costeffective analyze of wide areas, should be used in the most efficient way in water resources management.
In this study, the capability of the four remote sensing methods (NDWI, SVM, GEOBIA and GEOBIA_NDWI) was examined for water body extraction. By using these four methods, the superiority between the pixel-based and the objectbased classification, the superiority between the NDWI and the image classification methods and the contribution of the NDWI to the object-based classification were tested. The main findings of this study can be listed as follows:

- Meteorological factors and irrigation were found to be effective in lake area variations. 
- Sophisticated image classification methods tested in this study rely on human expertise and contain high computation, but simple NDWI water index could detect water bodies more accurate, faster and easier than others.

- NDWI allowed for better identification of the lake boundary and a better separation of the land cover classes adjacent to water at the border.

- The object-based classification was better than the pixel-based classification for distinguishing water and other land cover classes adjacent to border.

- GEOBIA supported by NDWI (GEOBIA_NDWI) produced better results than the standard object-based classification.

- Deleted mixed pixels out of the lake area was determined less in the results of NDWI and GEOBIA_NDWI.

This study demonstrates the role and importance of remote sensing in natural resources management, and specifically the results clearly show that the practical, easy and fast NDWI water index, which is created according to the spectral features of water, provides great advantages in the management of water resources. Future research will include more classification methods, different parameter values of the classification methods and the effect of other meteorological parameters such as evaporation on the water body change.

\section{Acknowledgments}

The author would like to thank the United States Geological Survey (USGS) for the Landsat satellite images, the General Directorate of State Hydraulic
Works (DSI) for the in-situ lake measurement data, and the Turkish State Meteorological Service (MGM) for the meteorological data.

\section{REFERENCES}

[1] Demirel K. and Kavdır Y., Effect of Soil Water Retention Barriers on Turfgrass Growth and Soil Water Content, Irrigation Science, 31-4 (2013) 689-700.

[2] Genç L., Demirel K., Çamoglu G., Asık S. and Smith S. Determination of plant water stress using spectral reflectance measurements in watermelon (citrullus vulgaris), AmericanEurasian Journal of Agricultural \& Environmental Sciences, 11-2 (2011) 296304.

[3] Çamoğlu G., Demirel K., Genc L. Use of infrared thermography and hyperspectral data to detect effects of water stress on pepper, Quantitative InfraRed Thermography Journal, 15-1 (2018) 81-94.

[4] Özelkan E. and Karaman M., The Analysis of the Effect of Meteorological and Hydrological Drought on Dam Lake via Multitemporal Satellite Images: A Case Study in Atikhisar Dam Lake (Çanakkale), Omer Halisdemir University Journal of Engineering Sciences, 7-2 (2018) 1023-1037.

[5] Karaman M., Budakoglu M., Uca Avci Z.D., Özelkan E., Bülbül A., Civas M. and Tasdelen S., Determination of Seasonal Changes in Wetlands Using CHRIS/Proba Hyperspectral Satellite Images: A Case Study from Acigöl (Denizli), Turkey, Journal of Environmental Biology, 36 (2015) 73-83.

[6] Liu Z., Yao Z. and Wang R., Assessing Methods of Identifying Open Water Bodies Using Landsat 8 OLI Imagery, Environmental Earth Sciences, 75-10 (2016) 1-13.

[7] Karaman M., Özelkan E. and Tasdelen S., Influence of Basin Hydrogeology in the Detectability of Narrow Rivers by Sentinel2A Satellite Images: A Case Study in Karamenderes (Çanakkale), Journal of Natural Hazards and Environment, 4 (2018) 140-155. 
[8] Ji L., Zhang L. and Wylie B., Analysis of Dynamic Thresholds for the Normalized Difference Water Index, Photogrammetric Engineering \& Remote Sensing, 75-11 (2009) 1307-1317.

[9] Du Z., Li W., Zhou D., Tian L., Ling F., Wang H., Gui Y. and Sun B., Analysis of Landsat-8 OLI Imagery for Land Surface Water Mapping, Remote Sensing Letters, 5-7 (2014) 672-681.

[10] Gürsoy Ö., Atun R. Investigating surface water pollution by integrated remotely sensed and field spectral measurement data: A case study, Polish Journal of Environmental Studies, 28-4 (2019) 2139-2144.

[11] Gürsoy Ö., Birdal A., Özyonar F., Kasaka E. Determining and monitoring the water quality of Kizilirmak River of Turkey: First results, ISPRS - International Archives of the Photogrammetry, Remote Sensing and Spatial Information Sciences, XL-7/W3 (2015) 14691474.

[12] Kavzoğlu T. and Çölkesen İ., Destek Vektör Makineleri ile Uydu Görüntülerinin Sinıflandırılmasında Kernel Fonksiyonlarının Etkilerinin İncelenmesi, Harita Dergisi, 144 (2010) 73-82.

[13] Gürsoy Ö and Altun R., Comparison of Spectral Classification Methods in Water Quality, Cumhuriyet Science Journal, 39-2 (2018) 543-549.

[14] Kalkan K. and Maktav D., Nesne Tabanlı ve Piksel Tabanlı Sınıflandırma Yöntemlerinin Karşılaştırılması (IKONOS Örneği). In: III. Uzaktan Algilama ve Coğrafi Bilgi Sistemleri Sempozyumu, 12-15 October, Gebze Kocaeli, Türkiye, 2010.

[15] Belgiu M. and Drăgự L., Comparing Supervised and Unsupervised Multiresolution Segmentation Approaches for Extracting Buildings from Very High Resolution Imagery, ISPRS Journal of Photogrammetry and Remote Sensing, 96 (2014) 67-75.

[16] Çölkesen İ., Yomralığlu T. and Kavzoğlu T., Obje Tabanlı Sinıflandırmada Bölgeleme Esasına Dayalı Ölçek Parametresi Tespiti: WorldView-2 Uydu Görüntüsü Örneği, Harita Dergisi., 154, (2015) 9-18.
[17] Blaschke T., Object Based Image Analysis for Remote Sensing, ISPRS Journal of Photogrammetry and Remote Sensing, 65 (2010) 2-16.

[18] McFeeters S.K., The Use of Normalized Difference Water Index (NDWI) in the Delineation of Open Water Features, International Journal of Remote Sensing, 17 (1996) 1425-1432.

[19] Xu H., Modification of Normalised Difference Water Index (NDWI) to Enhance Open Water Features in Remotely Sensed Imagery, International Journal of Remote Sensing, 27-14 (2006) 3025-3033.

[20] Pôssa E.M. and Maillard P., Precise Delineation of Small Water Bodies from Sentinel-1 Data using Support Vector Machine Classification, Canadian Journal of Remote Sensing, 44-3 (2018) 179-190.

[21] Uca Avci Z.D., Karaman M., Ozelkan E., Kumral M., Budakoglu M., OBIA Based Hierarchical Image Classification for Industrial Lake Water, Science of the Total Environment, 487 (2014) 565-573.

[22] Karaman M., Budakoglu M., Uca Avci D.U., Ozelkan E., Bulbul A., Civas M., Tasdelen S., Determination of Seasonal Changes in Wetlands Using CHRIS/Proba Hyperspectral Satellite Images: A Case Study from Acigöl (Denizli), Turkey, Journal of Environmental Biology, 36-1 (2015) 73.

[23] Korzeniowska K. and Korup O., Object-Based Detection of Lakes Prone to Seasonal Ice Cover on the Tibetan Plateau, Remote Sensing, 9-4 (2017) 339.

[24] Olmanson L.G. and Bauer M.E., Land cover Classification of the Lake of the Woods/Rainy River Basin by Object-Based Image Analysis of Landsat and Lidar Data, Lake and Reservoir Management, 33-4 (2017) 335-346.

[25] Kaplan G. and Avdan U., Object-based Water Body Extraction Model Using Sentinel-2 Satellite Imagery, European Journal of Remote Sensing, 50-1 (2017) 137-143.

[26] Şensoy S., Demircan M., Ulupınar Y. and Balta Z., Türkiye İklimi, Turkish State Meteorological Service Report. URL: https://www.mgm.gov.tr/FILES/genel/makal 
e/13_turkiye_iklimi.pdf Retrieved February 10, 2019.

[27] Chen G., Özelkan E., Singh K.K., Zhou J., Brown M.R. and Meentemeyer R.K., Uncertainties in Mapping Forest Carbon in Urban Ecosystems, Journal of Environmental Management, 187 (2017) 229-238.

[28] Özelkan E., Sağlık A., Sümer S.K., Bedir M. and Kelkit A., Kentleşmenin Tarım Alanları Üzerine Etkisinin Uzaktan Algılama ile İncelenmesi-Çanakkale Örneği, Çanakkale Onsekiz Mart Üniversitesi Ziraat Fakültesi Dergisi, 6 (2018) 123-134. 